\title{
PATERNALISM, DISTURBANCE AND PARLIAMENTARY REFORM: SOCIETY AND POLITICS IN COVENTRY, 1819-32*
}

The procession of her ladyship [the Godiva procession at the Coventry June Show Fair] is merely a commemoration of the traditional release obtained by the "Fair Godiva" for the oppressed inhabitants of Coventry from the tyranny of a feudal baron. Now, thank Heaven, we have to celebrate a nobler triumph, - the freedom of our country from the mercenary grasp of that detested oligarchy - the Boroughmongering tyrants, and lordly oppressors.

Coventry Herald, 15 June 1832

We must recollect that Coventry is not the whole country.

Edward Ellice, MP for Coventry, ibid., 13 June 1834

Asa Briggs has pointed out that the parliamentary-reform movement of the early 1830's differed considerably in nature and direction between one city and another. In Birmingham, the middle and working classes usually co-operated. Class distinctions were blurred. Steam power and the factory - socially disruptive forces - were lacking. Master and artisan worked together in small workshops, frequently changed places with each other in a socially mobile city, and united in advancing an inflationary paper-money programme appropriate to the Midlands iron interests. These were concerned with the home market and the need for expansionist credit. In Manchester and Leeds, on the other hand, the classes were separated by the factory, and had competing reform movements. Manchester's middle-class reformers were concerned with the needs of the cotton industry's export markets; they wanted a stable metallic currency, and stressed the encouragement to trade that would follow the repeal of the Corn Laws. Often they presented repeal in terms the working class found uncongenial. ${ }^{1}$

Coventry was different from all three. Its industry had an outwork pattern, and lacked the powered factory. Manufacturers and artisans were not usually antagonistic, partly because of a paternalist system

* I should like to express my gratitude to Anne Digby and William Luckin, for very helpful advice given during the composition of this paper.

1 Asa Briggs, "The Background to the Parliamentary Reform Movement in Three English Cities (1830-2)', in: Cambridge Historical Journal, X (1950-52). 
that encouraged deference in artisans. Reformers from all classes cooperated in supporting the Whig Reform Bill. Radicalism hostile to its middle-class prescription was insignificant. In some respects, therefore, Coventry resembled Birmingham. But it displayed not the slightest interest in Attwood's paper-money schemes, and the practical economic benefit expected from reform was the repeal of the Corn Laws. Its economic attitudes were, like those of Manchester and Birmingham, "rooted in local soil". It exported nothing and thought only of expanding the home market; it saw as the obstacle, however, not inelastic credit and a deflationary currency, but foreign imports. In Coventry, the Reform Bill years were marked by the desire to get imports prohibited, and this was another movement which brought masters and men together.

One event sharply distinguished Coventry from the other three cities. Distress and unemployment, everywhere prominent in the Reform drama, helped in Coventry to lead to acts of industrial violence unusual in the city's history, and in 1831 to one of the most spectacular occurrences in it, the burning of Beck's silk mill, which is the climax of this paper. It is of course difficult to assimilate this incident to the picture of a city characterised by deference and class co-operation that is sketched above. It took place at the end of a long series of English disturbances that seem at first glance very like each other, and one may safely assume that the example of others helped to trigger it. ${ }^{1}$ But the generalising approach sometimes adopted in writing about these outbreaks may obscure the essential differences of quality that are among the historian's most vital concerns. Detailed examination of the Beck riot shows it to have been a disciplined, moderate and shortlived act, for narrow and limited ends, resembling far more the classic eighteenth-century food riot $^{2}$ than the week-long battles, ambushes and attacks on property and people in Merthyr Tydfil a few months before. In Merthyr, anger over earnings and conditions of employment, food prices and parliamentary reform fused together into a complex, insurrectionary movement, reflecting deep class antagonisms. ${ }^{3}$ In Coventry, the mill-burning was a brief perturbation in a usually peaceful city, and was unconnected (at least in terms of expressed aims and desires) with either parliamentary reform or the campaign for protection against imports.

1 George Rudé, "English Rural and Urban Disturbances, 1830-1831", in: Past \& Present, No 37 (1967).

2 E. P. Thompson, "The Moral Economy of the English Crowd in the Eighteenth Century", in: Past \& Present, No 50 (1971), esp. pp. $107 \mathrm{ff}$.

${ }^{3}$ D. J. V. Jones, Before Rebecca (1973), pp. 133ff.; G. A. Williams, "The Insurrection at Merthyr Tydfil in 1831", in: Transactions of the Honourable Society of Cymmrodorion, 1965. 
There were 27,000 people in Coventry in 1830 , over 5,000 of them being silk-ribbon weavers, the largest occupational group. Watchmaking, the second-largest trade, was much less important. Both were outwork trades. Of 5,000 looms in the city, no more than a few hundred were in manufacturers' loomshops; the great majority were owned or hired in ones or twos by master weavers, ${ }^{1}$ who worked them in the "topshops" attached to their houses, with the aid of their families and journeymen. Master weavers shaded into the ranks of the smallest manufacturers, while at the other end of the spectrum some manufacturers were very large indeed, Thomas Cope keeping nearly 400 looms in work.

From the late eighteenth century onwards, the long-term trend in the ribbon trade was expansion; Warwickshire was the only major British producer, and the import of foreign silks was forbidden until 1826, though smuggling was a constant nuisance. The trade was seasonal; it was usually slack in the winter, and busy in the spring. Periodically, there were serious slumps; one occurred between 1815 and 1819. Afterwards, trade improved for some years, but trouble returned when in 1826 the prohibition on imports was replaced by a tariff, as part of the first "free trade" measures. By 1829 continental producers linked up with British dealers and large quantities of French and Swiss ribbons were being brought in. Coventry manufacturers cut prices (and weavers' earnings) and their ribbons, protected by a tariff, became cheaper than continental imports. Nevertheless, French competition remained serious, especially in the fashionable market amounting to one third of the whole, and consisting of upper-class women in London and large provincial towns. By 1829 there was a disastrous slump in the ribbon trade. ${ }^{2}$

Quarrelling bitterly over wages, weavers and manufacturers agreed that the underlying cause of distress was the importation of foreign ribbons, which despite the tariff was usually called "free trade". Coventry argued that duties could not protect the trade against the smuggler, or women's preference for French "taste", or unfair foreign competition in price. "Now this is very plain, that it is all fudge to say we are protected by 25 or 30 per cent." 3 The ribbon trade should be defended, it was thought, by the complete prohibition of imports, strong rights of search and seizure for contraband, and harsh punish-

1 In 1838 there were $1,800,200$ of them women.

2 This sketch of the ribbon trade is based on P. Searby, "Weavers and freemen in Coventry, 1820-1861" (unpublished Warwick Ph.D. thesis, 1972), ch. 2. 3 Coventry Herald, 10 June 1831. 
ments for smugglers. After prohibition, British women could continue to enjoy French patterns because Coventry could copy them. ${ }^{1}$

These arguments were never accepted by Parliament or Government. From 1830 onwards the Board of Trade was controlled by enthusiastic commercial liberals. They believed that the remedy for smuggling was to lower the duty so that it became unprofitable. When money could be made out of it, the toughest measures could not stop smuggling, as the failure of France and Spain to end it on their borders showed. John Bowring, the Board of Trade official, argued that the only way to enable the Coventry industry to prosper was to expose it to the competition of the more efficient French industry, whose vitality was partly the result of Swiss competition. In cotton competition led to efficiency, and here the British industry was more energetic than France's because it was less protected. The import of cotton cloth into France was forbidden and there were bounties on exports; so French exports languished while Britain's bounded ahead: "wherever ignorance and inferiority have remained unprotected, intelligence and superiority have taken their place". And, added Bowring, pointing out repeatedly that imports had to be paid for by exports, to reimpose the prohibitory laws on silk goods would mean curbing the prosperity of cotton as well as silk: "the demand for the prohibition of French silk goods is, after all, only a demand that England should not export cotton goods to France". As to British women's preference for French ribbons, Bowring crushed the argument that it was an irrational caprice. "I think the opinion of the superiority of French silk goods, where taste is a part, is no more a prejudice than a feeling in favour of the works of Raphael is a prejudice." Coventry's remedy was not prohibition but better designed ribbons, the regulation of wages by malket forces, and the raising of productivity by the adoption of steam power and the factory. "I have no doubt a great deal of distress exists, and it demands all sympathy, but a great deal of distress does exist from the very fact that two and two make four." Bowring added that "you have a great deal of misdirected labour, and in some departments a great excess of labourers"."2

During the Reform Bill crisis, weavers and manufacturers mounted a determined campaign to get prohibition reintroduced. This was immediately after the burning of Beck's mill - no coincidence. The burning led masters to guarantee higher piecework rates; they tried to prevent the full operation of market forces for social reasons. This threatened to increase the power of continental competition, and so

1 Report from the Select Committee on the Silk Trade [Parliamentary Papers, 1831-32, XIX], pp. $19 \mathrm{ff}$.

${ }^{2}$ Ibid., pp. $510 \mathrm{ff}$. 
made the ending of "free trade" even more necessary. "An Observer" wrote of prohibition at this time, when the agitation for the Great Reform Bill was at its height: "To the people of Coventry I am sure that this subject is more important than Reform itself." "A Manufacturer" declared:

"My circumstances, like those of most of my neighbours, resemble the man imprisoned in an iron room, which became narrower every day, till at last it became his coffin and his tomb. The prisoner is a personification of my trade; the unanimous resolution of the meeting of masters last week, calling for a memorial to the Board of Trade, is like the sound of trampling feet outside the prison."'1

But the reformist MPs for the city, Edward Ellice and H. L. Bulwer, gave the campaign little encouragement; it produced merely a select committee on the silk trade, which made no recommendations. ${ }^{2}$ In 1834 Coventry made the last organised attempt to get prohibition restored. Bulwer tried to introduce a bill to forbid imports. The two Tory members for North Warwickshire voted for his unsuccessful motion. Ellice spoke against. Throughout, he refused to assist the campaign. It was hopeless. In any case, how could smuggling be stopped? He pointed out the folly of considering Coventry's needs without reference to the widespread desire for free trade elsewhere in Britain. "We must recollect that Coventry is not the whole country; and that, even supposing the trade of Coventry would benefit to the extent some of the parties interested in it suppose, by the re-enactment of prohibition, it is vain to prosecute an application for measures to render that effectual." 3

Weavers were paid by piecework. In good times, piecework rates were standard, by a "list of prices", and there was a powerful tradition in the city of working with the weavers to keep them so. Manufacturers liked a list because it prevented ruinous competitition; their habits of relatively disinterested paternalism were important too. In addition, public opinion backed the weavers, arguing the claims of benevolence, and the need to maintain the flow of weavers' pay at a high level -

1 Coventry Herald, 18 November 1831.

2 Ibid., November 1831 to July 1832; Ellice to W. Hickling, 25 January 1832, Coventry Record Office (hereafter CRO), Miscellaneous Letters.

3 Coventry Herald, May and 13 June 1834; Parliamentary Debates, Third Series, XXIV, pp. $570 f f$. 
since very many inhabitants were dependent on the ribbon trade and a fall in earnings affected shopkeepers badly. In return, weavers adopted only those peaceful methods of suasion that citizens would approve: the procession, the placard, the meeting, the strike, with nothing more violent than the ceremonial humiliation of recalcitrant masters by riding them through the streets on donkeys. Lawless incidents were exceptional. ${ }^{1}$

Revealing examples of the ways in which weavers and other inhabitants behaved, and influenced each other, occurred in the slump after the French wars; many weavers were unemployed and masters abandoned the list of prices. After an unsuccessful attempt to get an Act of Parliament to regulate wages there was in August 1819 a general strike of weavers and some "donkeying". The masters were not otherwise harmed; the coercion was disciplined and moderate. The Coventry postmaster praised the weavers.

"This city is a loyal city as any place in this kingdom. Politics have nothing to do with the present question. The men in my opinion have been very ill-treated by some of their masters. It is only a turn-out for the men not to work any longer at the reduced prices, while a number of masters are paying $£ 10$ per week more wages for the same work. Many thousands have gone through the city with an ass, and have done what they call a little justice but they were stopped with perfect ease, and have promised not to give the least offence." 2

The magistrates (that is, the mayor and aldermen) agreed to the weavers' request that they should help in bringing pressure to bear on the manufacturers, and got them to draw up new lists of prices largely repetitions of the lists of 1816 . At the same time the magistrates warned that any further tumultuous assemblies would be punished. Weavers were told by their leader, Peter Gregory, that the warning must be obeyed: they must not even press reluctant weavers to strike. "None should go from that meeting with a resolution to compel people to leave their work, as that would be deemed tumultuous; it must be a voluntary act in all." 3 Within days, every manufacturer in Warwickshire had signed the new lists, and the weavers returned to work. 1,200 strikers' families were relieved by a distress fund to which many inhabitants subscribed, the corporation giving £25. The distribution

1 Searby, "Weavers and freemen", op. cit., pp. $32 \mathrm{ff}$.

2 Postmaster, Coventry, to Francis Freeling, 20 August 1819, Home Office Papers 42/192, Public Record Office, also in A. Aspinall, The Early English Trade Unions (1949), p. 321.

3 The Times, 25 August 1819. 
of money was supervised in each ward by its alderman. ${ }^{1}$

A public meeting at which the mayor took the chair considered the future of the lists of prices; leading men of the city attended. Peter Gregory "should not again have presumed to address so respectable a meeting, had he not been prompted by the noblest feeling of the human mind - gratitude." Drawing attention to the weavers' peaceful behaviour, he referred to the mayor's admonition against violence. "The handbill signed by you, Sir, was received with the utmost deference and respect." Charles Lilly, ribbon manufacturer and veteran leader of the Da1k Blue (or Liberal) party, praised the strike: its aims were not to raise wages, but to stabilise them at the level of the list. The success of the weavers in regaining the list would be to the advantage of the town as a whole; $£ 1,000$ more, each week, would be paid to weavers, and would be spent in the city. Weavers should strive to maintain the list, and the town should help them. "If the prices that are now obtained are deviated from at future times, it will be the fault of the journeymen." Lilly recommended "that they should refrain from work, rather than take it at an inferior price". He would subscribe to a second relief fund, to sustain the list. Thomas Cope agreed with him, pointing out that to maintain the list would be to help the poor rate. ${ }^{2}$ The second fund was opened, with Lilly as its treasurer, and subscriptions were raised in Coventry and London. "This being the case, it is presumed no mean master or dastard weaver will ever deviate from the list prices." 3 By April $1820 £ 1,600$ had been raised for the fund - many manufacturers contributing to it. ${ }^{4}$

Very soon the weavers elected a committee, the Aggregate Committee, to maintain the list. Its purpose was to bring pressure to bear upon those who offered or accepted lower prices than the list laid down. Only one man, Farrington, consistently refused to pay by the list. The Aggregate Committee interviewed Farrington's weavers, and induced them to stop working for him by vague threats (though no actual injury seems to have been inflicted on anybody) and by a promise of financial support. The committee had special funds to pay unemployment benefit to weavers refusing to work below list prices. There were levies of one penny or halfpenny a week on each loom, according to its size; "those who refused to pay were held up to the derision of their neighbours". The money was held in trust by a

1 Ibid., 20 and 25 August, 1 September; Manuscript of William Reader, f. 168, Bodleian Library, Oxford, MSS Top. Warwickshire C 4.

2 The Times, 25 August 1819.

3 Ibid., 1 September.

4 Report of the Royal Commission on the Handloom Weavers, Assistant Commissioners' Reports, Midland District [PP, 1840, XXIV], p. 217. 
"respectable tradesman" in each ward. Whenever this fund was exhausted, the Aggregate Committee was able to draw upon another - the second distress fund set up by public subscription in 1819. Payments continued for some years, until disaster struck. Troughton's bank went bankrupt and lost over $£ 1,500$ of the fund's money. Soon afterwards, Farrington won an action for loss of trade against Lilly and the secretary of the Aggregate Committee at Warwick Assizes. ${ }^{1}$ Then Lilly and seven others were indicted at Coventry Quarter Sessions for conspiracy under the Combination Acts. "The treasurer being a very respectable man, other respectable persons endeavoured to effect a compromise. The whole of the fund was given up, and the poor men acknowledged their offence by a public advertisement, and the prosecutor dropped it."' Lilly and company agreed to pay the costs of the prosecution and transfer the residue of the fund to the Coventry street commissioners; most probably, the $£ 300$ that Lilly paid to them "towards making up a new road in Broad Gate" was the distress-fund conscience money. ${ }^{3}$

To meet continental competition after 1826 , manufacturers cut piecework rates. The list of prices of May 1826 registered reductions of 20 per cent; they help to explain the weavers' turning against their masters' candidate at the general election in June. By 1829 even this list was abandoned, and a new list in September 1829 recognised and regulated current lower prices. Some masters wanted to pay even less, and refused to sign it. But most manufacturers were anxious to avoid cut-throat competition; a list was valuable for them. Among inhabitants there was fear of the effect that reductions would have on shopkeepers, the poor rates and public order. One reducing master's windows were broken by a crowd of weavers; he kept them off his property with a loaded blunderbuss. ${ }^{4}$ So in September 1829 the Directors of the Poor, the mayor and the magistrates persuaded reluctant manufacturers to hold to the list. Things were very bad for the weavers; paternalism and civic self-interest prevented them from being even worse. ${ }^{5}$

1 Warwick and Warwickshire General Advertiser, 6 April 1822.

2 Sixth Report from the Select Committee on Artisans and Machinery [PP, 1824, V], p. 603; Warwick and Warwickshire General Advertiser, 12 April 1823. 3 An Account of the Receipts and Payments by the Commissioners [...], May 1823 - May 1835, CRO; Coventry Herald, 26 May 1826.

4. Whitwell to Sir Robert Peel, 7 May 1829, HO 40/23; R. Woodcock to Sir Robert Peel, 18 September 1829, HO 40/24/2.

${ }^{5}$ Coventry Observer, September and October 1829; Report on the Handloom Weavers, Midland District, op. cit., p. 219; P. Searby, "'Lists of Prices' in the Coventry silk industry, 1800-1860", in: Bulletin of the Society for the Study of Labour History, No 27 (1973). 
In the spring of 1829 , out of 5,000 looms in the city 2,000 were totally idle and the rest often so. Numbers on poor relief soared; by January 1830 1,395 able-bodied families were receiving outdoor relief, three times as many as one year before. The poor rates climbed. Even so, the bank account of the Directors of the Poor was overdrawn by more than $£ 4,500$ early in $1830 .^{1}$ These were the years remembered a lifetime later by Joseph Gutteridge, as marked by experience "bitter indeed, particularly in the severe winter, with bread at famine prices, and potatoes spoiled by the frost so as to be almost uneatable. These were times of suffering not easily forgotten."'2 In the summer of 1831 the crisis was so bad that a further 15 percent reduction in the lists was proposed. Weavers met to address the manufacturers, appealing to their self-interest and local loyalties. "Gentlemen, you are in some instances our kinsmen, and with few solitary exceptions, our immediate neighbours. The City that gave you birth is the place of our nativity." Any lowering of weavers' earnings would merely mean that wholesalers would cut their prices, and that shopkeepers would lose income.

"But above all, consider the time when this attempt is made. It is in 1831, the year big with such momentous events, - the time when freedom and liberty are making rapid marches, and the fetters which have bound so many of the nations of Europe are about to be broken, - the year in which Britons anticipate the commencement of that improvement which will gradually restore those comforts their fathers enjoyed."'3

All except three of the city's manufacturers (more than sixty, that is) replied by saying that they wanted to hold to the list of prices; the three went ahead with a reduction that no one could stop. Infringements of the list became general; by the autumn some weavers were earning less than they would have got from parochial relief. $2 / 6 \mathrm{~d}$ was being paid for work for which the list price was $7 / 6 \mathrm{~d}$. Masters still paying by the list announced that they must lower their piecework rates unless the underpaying stopped; another reduction of the list was threatened in November. ${ }^{4}$ The anger of the weavers at low piecework rates then fused with their hatred of innovations exacerbating

1 Report on the Silk Trade, op. cit., pp. 26ff.; Coventry Observer, 2 April 1829; Proceedings of the Guardians of the Poor, pp. 97ff., CRO.

2 Joseph Gutteridge, Lights and Shadows in the Life of an Artisan (1893), p. 30.

3 Coventry Herald, 10 June 1831.

${ }^{4}$ Ibid., June and July; Report on the Silk Trade, pp. 59, 105; Report on the Handloom Weavers, Midland District, p. 220. 
the surplus of labour or undermining the outdoor system. There followed the most spectacular act of industrial violence in Coventry's history - the burning of Beck's mill.

\section{III}

The 1832 Reform Bill got keen support from most people in the city. Much of it was disinterested, coming from a group liable for disfranchisement under the bill as first drafted. One direct economic benefit was expected from Reform - the repeal of the Corn Laws. The city's Liberal newspaper wrote:

"Two county men were talking, during the chairing at Warwick, and one said to the other, 'What does this reform mean?' 'Why,' replied his companion, 'I'm an older man than you, and can recollect when we had better flour for eighteen-pence a stone, than we have now for half-a-crown; and it is to bring down the price of flour as it used to be'. 'Well then,' said the younger, 'if that's it, it's worth trying for'. 'Now that it is, and it is worth trying for'."'1

In Coventry, the freemen composed the large electorate; in 1826, for example, there were more than 3,300 electors, more than 600 of them living outside Coventry - as far away as Calais or Cornwall. Elections were often contested, turbulent, drunken and costly. Each supporter of the winners was paid 5/- after a contest. Public houses were kept open during elections at candidates' expense; "buttered ale" was a local speciality. At the 1826 election (a notorious contest) the Tory corporation exploited the weaver's sense of grievance against the Liberal candidates favoured by their masters. (Piecework rates had just been reduced.) Tory supporters were promised charity doles or places in almshouses under corporation control; bullies were hired and mobs refreshed with gin; Liberal supporters were beaten up and had their clothes ripped off. Six years later the Liberal organisers got their revenge, with mobs led by local pugilists such as the "Chicken Butcher". A Tory solicitor said to Ellice, the Whig MP: "This is a dreadful way the men are being beat", to which Ellice replied: "It is not worse than 1826; it is what is usual at elections." 2 Ellice wrote in 1832 that foolish would be the candidate

1 Coventry Herald, 13 May 1831.

${ }^{2}$ Report from the Select Committee on the Coventry Election [PP, 1826-27, IV], pp. 7ff.; Report from the Select Committee on the Coventry Election Petition [PP, 1833, VIII], pp. 17ff., 93; Report from the Select Committee on Bribery at Elections [PP, 1835, VIII], pp. 60ff.; The Times, 16 June 1826. 
"who supposes an election at Coventry has been, or will be, an affair of principle. True, that a reformer with money, may beat a candidate with, or without that essential 'interest' - but you may know what chance a reformer without money, will have against an anti-reformer with a long purse." 1

It is sometimes hard to see principle at work in Coventry politics. In fact, left to themselves most Coventry electors were usually Liberals. From 1803 to 1826 the most popular MP was Peter Moore, a Foxite Whig, an opponent of the French wars and a supporter of Catholic emencipation, parliamentary reform and the rights of artisans; he helped to get the Combination Acts repealed in 1824. From 1818 his colleague was Edward Ellice, brother-in-law of Earl Grey of the Reform Bill, a Scot with large estates in Canada, a good-humoured and adroit man. ${ }^{2}$ Moore and Ellice drew support from the 4,000 who met in 1817, at the depth of the depression in the ribbon trade, to protest at high taxation, placemen and an unrepresentative Parliament. ${ }^{3}$ This movement for reform was large, but almost always legal, moderate and peaceful. In 1817, for example, Major-General James Lyon, commanding the Midland District, found Coventry one of the least troublesome places in his charge. In the spring, the "moral rectitude of the lower classes" was shaken by a "long uninterrupted circulation of blasphemous and seditious publications", but "the state of the public mind" was "tranquil". He moved two companies of foot to Birmingham from Coventry, "less vulnerable under existing circumstances". By the end of the year he could report that the "numbers of the disaffected who are known to assemble sometimes are said to be insignificant and few". There were no Hampden Clubs in the city. There was a dispute over wages, but the people were "generally loyal and attached to His Majesty's Government". ${ }^{5}$ Meanwhile, in Birmingham signatures were being collected for a petition for parliamentary reform, and Lyon considered for a time transferring two more companies of foot there from Coventry. ${ }^{6}$

A strong reason for the constitutionalist nature of Coventry Radicalism was the pattern of labour relations, as is shown by the events that followed Peterloo in 1819. The mayor was asked by 700 in-

1 Ellice to W. Hickling, 1 March 1832, CRO, Misc. Letters.

2 Dictionary of National Biography, sub voce; Searby, "Weavers and freemen", pp. 30ff.; Prosper Mérimée, Etudes Anglo-Américaines (Paris, 1930), pp. 242ff. 3 At a most numerous and respectable meeting, 28 January 1817, Coventry City Libraries, Coventry and Warwickshire Collection, Broadsides Collection.

4 Lyon to Sidmouth, 10 and 15 May 1817, HO 40/6.

${ }^{5}$ Lyon to Sidmouth, 7 December 1817 , HO $40 / 6$.

- Lyon to Sidmouth, 2 December 1817, HO $40 / 6$. 
habitants to call a public meeting of protest. As hostile to Radicalism as to wage-cutting, he refused. Nevertheless, plans for a meeting went ahead. The Weavers' Committee promptly placed an advertisement in the Coventry papers expressing "detestation of all revolutionary principles" and deploring the meeting: the earnings of weavers had lately been raised and they needed no radical reform - which was indeed likely to have a bad effect on trade. The advertisement is a graphic demonstration of the mutually sustaining rapport between the paternalist attitudes of the city and the moderation of the weavers. A few weeks before, the weavers had been indebted to the city establishment for their victory over the list of prices, and the fund set up to maintain it. In the event, only 200 Coventrians turned up at the protest meeting, though it was well publicised and was held on 15 November, the day of so many demonstrations throughout Britain. ${ }^{1}$

Eleven years later, the chairman of this Greyfriars Green meeting (James Grant, a Broadgate chemist) was a prominent member of the Coventry Political Union, founded early in 1830. Other known members include a "gentleman" (William Gregory of Stivichall Hall), a hatter, a currier, a printer, two solicitors, the market-toll collector, two ribbon manufacturers, six weavers and a watchmaker. ${ }^{2}$ This list seems to suggest that a broad social spectrum was represented in the union, but since it is based on press reports of those speaking at meetings it tends, most probably, to overestimate the proportion of middle-class members. A leader declared in September 1830 (when there were 300 members) that the union consisted predominantly of poor men, meeting together for "mutual instruction". "The time was arrived when the people saw that it was only through their own ignorance of the political state of the country, that these aristocrats were enabled to uphold their dominion over the wealth of the nation." The union was far more encouraging to working men than, for example, the Manchester Political Union, an exclusivist middle-class body. A scale of subscriptions starting at $1 \mathrm{~d}$ a month (entitling members to attend monthly meetings) allowed the poorest to join; the fullest subscription was $2 \mathrm{~d}$ a week, giving access to weekly meetings, and the union's library and reading room. ${ }^{3}$

At meetings members attacked the Corn Laws, tithes, the East India Company's Charter, the newspaper-stamp duty and high ad-

\footnotetext{
1 Newspaper cutting of the meeting, Bodleian Library, Oxford, Gough Add. Warwickshire, b 2; Manuscript of William Reader, op. cit., f. 169.

2 Searby, "Weavers and freemen", pp. 124ff.

${ }^{3}$ Coventry Herald, 10 and 17 September $1830 ; 7$ and 28 January 1831; Coventry Observer, 11 and 25 March 1830; Briggs, "The Background of the Parliamentary Reform Movement", loc. cit., p. 307.
} 
vertisement duties. ${ }^{1}$ Discussions centred on the need for parliamentary reform. From the first members seemed willing to accept a moderate degree of reform and unwilling to use any but peaceful methods to achieve it. In July 1830 George Edmonds, the Birmingham Radical, came to discuss parliamentary reform. Edward and Samuel Burdett argued that the union should press for annual parliaments, universal suffrage and the ballot. Edmonds and others replied that the best hope for reform was in a union of the middle and working classes for moderate changes, and that the Burdetts' demands could only be achieved by a revolution. Edward Burdett disagreed: "I have a large family, and to suppose me friendly to a revolution, would be to say that I had no affection for them. I am not a revolutionist." But the motion for moderate reform was carried. ${ }^{2}$

The French Revolution of July 1830 perceptibly heightened the union's rhetoric: "their bright example will spread far and wide [...]. One tyrant has fallen - others are trembling." At the September meeting several members wore tricolour ribbons, and James Grant announced that "the example set in France, must have some effect in promoting a Reform in this country"; Thomas Goode wished "every one now to come forward and assist in the great work of Parliamentary Reform, as that was the only thing that would redress the wrongs of the people of England". ${ }^{3}$ In the new year Henry Hunt visited Coventry, and called for radical reform. When he asked for support, all his hearers raised their hands for the ballot. A few months later, resolutions for manhood suffrage and the ballot were carried at a meeting of the CPU addressed by Henry Hetherington. ${ }^{4}$ The evidence suggests that reformists were ready to articulate demands for radical change, but were really unprepared to rock the Whig boat. At the end of 1830 another reformist society, the "Friends of the People", was founded in Coventry "for the diffusion of political information on the principles of Radical reform". Its weekly subscription was $\frac{1}{4} \mathrm{~d}$ so that all might join. Thirty joined in the first few months, some being also members of the political union. Members were particularly enthusiastic for the ballot; the committee was chosen by ballot to show its value in parliamentary elections. ${ }^{5}$ Shortly before the election of 1831 the Friends of the People issued a handbill that called in strong

\footnotetext{
1 Coventry Herald, April 1830 to March 1832; Poor Man's Guardian, 24 March 1832; H. L. Bulwer to W. Hickling, 27 January and 27 March 1832, CRO, Misc. Letters.

${ }^{2}$ Coventry Herald, 9 July 1830.

3 Ibid., 3 and 10 September.

4 Ibid., 14 January and 29 July 1831.

5 Ibid., 26 November 1830 to 18 February 1831.
} 
language for parliamentary reform. After attacking the boroughmongers it proceeded: "Almighty God! What rights have the poor of this realm ever enjoyed beneath their iron tyranny and plundering sway? unless it be the right of starvation, the right of incessant trial and labour, of hourly anxiety, withering poverty, and actual want." Its conclusion was an anti-climax - a call for support for the Whig bill. ${ }^{1}$

At the 1831 election reform was the overriding issue. The sitting members were Ellice and T. B. Fyler, returned at the uncontested election of 1830 . Ellice was wholeheartedly committed to the Whig bill; indeed as chief whip he was helping to steer it through the Commons. Fyler's position was ambiguous. He announced that he was a "sincere, but moderate, reformer". But though he voted for the second reading he refused to give explicit assurances that he would not try to get it altered in committee. The Dark Blues (the Liberals) would not support him. Henry Lytton Bulwer, the younger brother of the novelist, was persuaded to stand with Ellice. They spoke and campaigned together, and were returned with large majorities. Afterwards came the usual "chairing" ceremony: the victors were carried round the town on chairs covered with dark-blue satin and surmounted with a canopy of dark-blue silk, which was supported on lofty fluted pillars and decorated with a gold fringe and tassels and a gilt ball bearing a laurel. $^{2}$

Coventry's special interests were closely affected by the Reform Bill. Its first version, published in March 1831, laid down that the freeman franchise, like all ancient borough franchises, was to be abolished for all except those already possessing it. This meant that even Coventry apprentices already indentured would not get the vote when they became freemen. Lord John Russell argued that "I contend, that it is important $[\ldots]$, to give to the real property and to the real respectability of the different cities and towns the right of voting for Members of Parliament." The ancient-right electors, frequently from the lowest class, were corrupt and added to the expense of elections, which the Government wanted to reduce. ${ }^{3}$ All Whigs took this line. Some Tories argued for the ancient franchises, for example Sir Robert Peel:

"I think it an immense advantage that the class which includes the weavers of Coventry and the potwallopers of Preston has a share in the privileges of the present system. The individual right

1 Ibid., 29 April 1831.

2 Ibid., April and May; Coventry City Libraries, Coventry and Warwickshire Collection, Broadsides Collection.

${ }^{3}$ Parliamentary Debates, Third Series, II, pp. $1061 \mathrm{ff}$. 
is limited, and properly limited, within narrow bounds; but the class is represented. It has its champion within your walls, the organ of its feeling, and the guardian of its interests."'

The Government conceded in April 1831 that apprentices already bound should keep their franchise. But further adjustments were refused, despite much Tory pressure in favour of freemen during the committee stage and in the Lords; the other ancient franchises got much less support, presumably because they were thought to be less "chartered" or imprescriptible. In the autumn, however, the Government bowed to the Tory campaign by conceding the retention of the freeman franchise (for resident electors) in the hope that it would help the passage of the bill through the Lords. ${ }^{2}$

Until this compromise, Coventry Radicals were annoyed that future freemen were not to get votes, and that the popular nature of the constituency was to be lessened. That they stayed in support of the bill shows their devotion to national reform rather than local and particularist advantage - an exceptional attitude, since throughout the rest of the century Coventry freemen were intensely and exclusively loyal to their own interests. The question was debated in the County Hall in July 1831. Thomas Newsome, a weaver, attacked the betrayal of local rights: "If the bill now before the House of Commons extended to every householder in the kingdom, he would not be willing to give up his right of franchise. ('Shame, shame.') The bill for Reform went to cut off the rising generation. (Laughter.) It cut off expectancy. (Renewed laughter.)" He supported a resolution to retain the freeman franchise. Another weaver, William Fletcher, moved an amendment calling for the extension of the franchise to all who paid scot and lot. Dr Fitzpatrick supported it and claimed that the original resolution "was only a side wind to get rid of the bill". He added that "to the Tories they were indebted for all the ills under which the country laboured". There were cheers and cries of "It's false". Edward Goode, another weaver, stressed the need not to damage the Reform Bill; he wished that the potwalloper and freeman franchises had been kept and the suffrage in general extended, but to press for the continuance of this right for Coventry would tend to

"endless litigation from one end of the land to the other. If the men of Coventry said, 'Continue our rights by servitude', the men

1 Ibid., p. 1346.

${ }^{2}$ D. le Marchant, Memoir of John Charles, Viscount Althorp, Third Earl Spencer (1876), pp. 372ff.; Michael Brock, The Great Reform Act (1973), pp. $266 \mathrm{ff}$. 
of Leicester would also say, 'Continue our eldest sons'. (A voice in the crowd: 'Let them do as we do, look to their rights'. Uproar.)"

Goode "thought their attention ought to be directed to the means of obtaining a cheap loaf, - to some plans for relieving the national distress, than [sic] to such trifles as maintaining exclusive privileges". Thomas Perkins clinched the debate: "While all Europe was in a blaze, determined to assert their rights, were they - the men of Coventry to stand cavilling about their petty localities?" He asked: "Were they to annoy the Government, which was willing to concede to right and reason that which could only be wrung from tyrants of other lands by bloodshed and confusion?" Fletcher's amendment was carried by a sweeping majority. ${ }^{1}$

The rejection of the bill by the House of Lords in October 1831 led to a demonstration that provided a striking picture of Coventry Radicalism and civic unanimity. A large public meeting was convened by the mayor in Cross Cheaping. From the balcony of the City Hotel speeches against the bishops and Lords were made by men of very different social origins: a ribbon manufacturer, a banker, a country gentleman, and two ribbon weavers - Edward Goode and David Smith. Smith spoke of the "duty of all, rich and poor, to come forward in support of his Majesty's ministers". Goode said that "they had met, not as anarchists, but as friends of order". His words reflect the moderate nature of his reformism and his self-effacing acceptance of rank and class. They help one more fully to understand his horror at the burning of Beck's mill, one month after this Reform Bill meeting.

"It would have been gratifying to him to have occupied a place in the crowd below, and to have given place to men more respectable in circumstances and efficient in ability than himself; but he appeared as the humble representative of the great crowd of artisans by whom he was surrounded, and he could assure them he considered it no small honour to address such an assembly."2

There were Coventry Radicals who, had they been invited to speak at the October meeting, would not have done so in terms like Goode's: men such as those (whoever they were) who after the bishops voted against the Reform Bill caused Edward Bromfield to issue, on behalf of the Friends of the People, a handbill which the city's steward"read with horror at Quarter Sessions:

"To the people of England! Pay no more tithes! No more Church Rates! - without compulsion; but, in God's name, do not withhold

1 Coventry Herald, 8 July 1831.

${ }^{2}$ Ibid., 14 October. 
payment of the Taxes; rather contribute an extra mite, if necessary, to support the King and his ministers in this fearful emergency. Mark your detestation of the haughty, heartless and overgrown Hierarchy, by absenting yourselves and families from your Parish Church!"'

The existence of uncompromising Radicalism in the city is further demonstrated by the widespread circulation of unstamped newspapers in the city (fifteen men being committed by Coventry magistrates for selling them early in March 1832), and perhaps by the way "nearly 100 most respectable tradesmen and artisans" chose to celebrate the General Fast Day in the Coventry Political Union's rooms in March 1832. They "sat down to a most excellent dinner, of hot beef, boiled legs of mutton, roast veal, etc., etc. [...] Two handsome plates were first cut off, and sent, with a jug of best ale, to the victims of the knowledge-gagging laws" in Coventry gaol. ${ }^{2}$

Yet Goode's words at the October 1831 meeting suggest how potent habits of deference could be in a Coventry Radical: and the meeting itself seems to reflect a broad and united civic enthusiasm for the bill a feeling shown by Henry Wreford, the Unitarian minister, whose name is never otherwise attached to political activities and who confessed as much. But, "the system of non-representation was productive of much crime and immorality". ${ }^{3}$ These impressions are reinforced by the conduct of a public meeting held on Greyfriars Green during the ciisis week of May 1832, when the Lords threatened the bill and the Government resigned. Before the meeting the Coventry Political Union rallied the town, with the flag of the union and a banner bearing the slogan "Our patriot king and the people" - with the first three words covered with black crape and the phrase "A Cheap Republic" substituted. There was also a tricolour flag, "and about the middle of the procession was hoisted an effigy of the Gallant Duke, decked out in a suit of military indescribables". On Greyfriars Green the mayor and gentlemen were seated on waggons. They asked for the "Cheap Republic" flag to be removed. There were murmurings in the crowd, but when Arthur Gregory of Stivichall Hall appealed for its removal for the sake of civic unity it was taken away. The men who had spoken at the October meeting expressed support for the bill and the need for peaceable activity. Seven hundred new members joined the Political Union in the first three weeks of May, 200 of them on the day of the Greyfriars Green meeting. ${ }^{4}$

1 John Carter to Melbourne, 17 October 1831, HO 52/15; Coventry Herald, 21 October 1831.

2 Poor Man's Guardian, 24 March and 14 July 1832.

3 Coventry Herald, 14 October 1831.

4 Ibid., 18 and 25 May 1832. 
The news of the passing of the Reform Bill in June 1832 was followed by the substitution of emblems of Reform for Lady Godiva in the procession mounted at the June Show Fair. The procession paraded the town on Monday 25 June, led by some children bearing a banner with the device "May the hopes of the rising generation be realised", and then by the Champion of Reform in white armour, mounted on a charger and carrying the Reform Act. ${ }^{1}$ Also, at the meeting to organise celebrations it was proposed that windows should be illuminated. Some rich citizens countered the suggestion by offering to subscribe to a fund to provide comforts for the poor if it was dropped; they disliked the Reform Bill, and wished neither to pretend to like it nor to invite the stone-throwing that failure to do so would result in. Nevertheless, Radicals persuaded through a vote for illuminations on the grounds that "a good illumination was calculated to make even a dunce a good politician". ${ }^{2}$ It was said that the first meeting was thinly attended, and so another was held to reconsider the question. Almost everybody argued against illuminated windows; a collection for the poor would be much more useful. John Hands, a Liberal ribbon master, argued that the idea was a plot thought up by people who lived in courtyards, whose windows were less dangerously exposed than those on thoroughfares, and who would not have to put lamps in them anyway. Edward Goode's contention that the poor wanted to enjoy the lights cut no ice; but no decision was taken. Yet a third meeting decided against illuminations, despite much opposition from Edward and Thomas Goode. ${ }^{3}$ The celebrations over the passing of the Reform Bill aroused more controversial verbiage than the political debate itself had. This fact reflects the fear of the affluent and respectable that popular merrymaking, in a badly policed town, might quickly get out of hand and turn to popular violence - a feeling much aggravated by the burning of Beck's mill, just seven months before the Reform celebrations.

\section{IV}

Weavers detested innovations that exacerbated the surplus of labour, like the manufacturers' loomshops introduced in the 1820's in an attempt to meet foreign competition. These enabled manufacturers to bypass the effective restriction placed on entry to the trade by the usual requirement of master weavers that their apprentices should live with them; loomshops had a higher ratio of apprentices to looms

1 Ibid., 22 June.

2 Ibid., 15 June.

s Ibid., 22 June. 
(one to six) than the outdoor system (one to every nine or ten) because apprentices were a form of cheap labour. Loomshop owners exploited the chronic surplus of labour - trying to give constant work to the shops in which they had sunk capital, and turning off the outdoor looms in their service first when slumps came. And only the loomshop gave full opportunity to the dynamic manufacturer wanting to introduce more productive work rhythms or machinery: men like John Hall, who wanted to introduce into his Coventry loomshop some rack-and-bar looms that had done well in Coggeshall, Essex. He did not do so because of the bloody-mindedness of the Coventry weavers, though they were so much more expert than those of Coggeshall that he felt that if he could get them "working cordially with him" he would "defy the world" with his ribbons. He complained that "they had a combination among them, and would rather keep those men out of employ, to keep up their bad machinery, than suffer them to work for me". " For Hall's rack-and-bar looms, the outdoor weavers knew, would deprive them of work and end by driving them into the loomshop. Here they would lose the freedom and independence of the outwork system, and become factory hands under the scrutiny of a foreman directed to impose more intensive rhythms of work.

All the issues involved were brought sharply into focus by the story of John Day. About 1821 he was making ribbons in a small way, and learning the art of "shooting-down", or passing the shuttle between the warps. But instead of learning the weaver's other task, "pickingup" - tending and cleaning the warps -, Day "employed a second hand at weekly wages to pick". By 1826 he had ten looms in his loomshop and he turned all of them over to his separate picking-up system; it was profitable, especially when both shooter-down and picker-up were paid by the week and not by the piece. The shooting-down was done by men; picking-up was light work performed by women and girls: "and the advantage consists in the saving of the more valuable time of the man effected by the cheaper labour of the woman; their joint efforts turning off in a given time more work, as compared with the labour of a man only, than will pay for the services of the woman". Day thought that this method saved more than a quarter of the cost of weaving. ${ }^{2}$ At the depth of the slump in 1831 Day paid more than the going rates - between $16 /-$ and $24 /-$ a week to his men, for example -, but he got no credit for them, especially since the weavers knew that his own male outworkers, used as marginal labour to his Gosford Street loomshop, earned on piecework as little as $4 /-$ a week.

From the first, Day was opposed by all weavers. The men hated the

1 Report on the Silk Trade, pp. 372ff.

2 Report on the Handloom Weavers, Midland District, pp. $49 f f$. 
division of labour. It lowered their status, turning "the workman in the jacquard engine-loom from the rank of a somewhat skilled artisan to that of little more than a mere automatic treader of one treadle, and passer of one set of shuttles". It condemned them to continuous work, by removing from their weaving the intervals of picking-up. Weekly wages made matters worse, because they made it impossible for weavers to break off when they wanted to, as they did under piecework. Most important, there was a general feeling among weavers that making more ribbons with fewer hands was evil, and that the superior competitive power it gave to Day would lead to "a general introduction of the factory system of working on the master's premises at weekly wages, in lieu of being at home and paid by the piece" ${ }^{1}$ In the spring of 1829 , when the slump and unemployment made his new methods all the more hateful, a determined campaign against him began, with violence unprecedented in Coventry. Day and his wife wrote to the Home Secretary about it in April 1830:

"Your memorialists are absolutely fearful of their lives, as well as those of their children. This violence has been carried on now for twelve months; and it is not only against them and their family, but also against the persons in their employ; in the month of May last, a mob assembled in the street in which your memorialists reside, and waylaid their work-people, and so shamefully did they behave, that one of them, viz. Anna Maria Boydell [...], never recovered, nor ever did a day's work after, but lingered in great pain and agony, till the 13th of November last, and then died, from the bruises she received; [...] but this is not a tenth of the injuries your memorialists have been, and are subject to, - all manner of missiles and filth are constantly being dashed on and against their premises; but this your memorialists would not have noticed, had it not been for a more diabolical act committed on Thursday night last, [...] a train of gunpowder laid in an alcove situate in your memorialists' garden, behind their house, and which was set fire to, about 9 o'clock; - the concussion did infinite damage to the said alcove, and absolutely shook the foundations of the buildings in the surrounding neighbourhood!!!"2

Most probably, Day makes these incidents sound worse than they were. At all events, they were not enough to get him to change his methods. So tension continued. The long crisis over the list of prices worsened it. Thus Josiah Beck chose an unpropitious time to start

2 John and Sarah Day to Sir Robert Peel, 28 April 1830, HO 40/25. 
building a factory for power looms in August 1831. The factory was on the third floor of his house in New Buildings, near the Sherbourne and the Mill Dam. (Sainsbury's supermarket fills the site today.) By November nine power looms were ready or being installed; two belonged to Christopher Woodhouse, who was to pay 5/- a week for standing and steam. There was also a steam engine, winding machines, and a throwing mill filled with silk in the attic. ${ }^{1}$ Early in November 1831 the honourable manufacturers issued their warning that unless competitors stopped paying below the 1829 list they too would be forced to make reductions. By chalked notices on the walls of the town a weavers' meeting was called for the morning of Monday 7 November at Cross Cheaping; the purpose of the meeting was to seek the reestablishment of the 1829 list, not an increase in prices. Two hundred assembled at Cross Cheaping; they dispersed to collect more men and met again in the George Inn in Little Park Street at 10 a.m. Here a committee of seven master weavers, including Edward Goode, David Smith and George Baddeley, was appointed to ask for the help of the magistrates in pressing the manufacturers to reaffirm the list. It was decided to hold another meeting at Cross Cheaping at 2 p.m. to receive a report from the committee. The morning was peaceful; no violence occurred or was expected.

The magistrates promised the committee of seven their help if it was needed. About midday the seven met the manufacturers' committee and asked them to convene a meeting of the manufacturers; it was agreed that the two committees should meet together at 2 p.m. At 2 o'clock the manufacturers' committee asked for a delay of half an hour. The seven departed to meet the weavers they thought would be gathered at Cross Cheaping. They found nobody there. While waiting for their committee the weavers had met by chance Josiah Beck, the proprietor of the factory; in a growing mood of excitement and anger they got into an argument with him about the making of ribbons by steam when handloom weavers were unemployed. Shortly before the committee arrived, the weavers moved off towards the factory in a menacing mood, taking Beck with them. The committee "were then very anxious to go down and draw the men away [...]; but they were checked by the thought, that by so doing they might expose themselves to the suspicion of being promoters of the mischief."2 Perplexed, they arrived at Samuel Hennell's house in Hill Street after 3 p.m. to keep their appointment with the manufacturers' committee. Hennell took them to the top floor of his warehouse, and

1 Coventry Herald, 30 March 1832.

${ }^{2}$ Report on the Handloom Weavers, Midland District, p. 220. 
showed them columns of smoke rising from Beck's factory nearly a mile away. ${ }^{1}$

About 3 p.m. 200 men had arrived at Beck's house and asked to see his machinery. Beck, temporising, said that he was willing for one man to look at it and invited Joseph Day, a weaver, inside. There was a general rush forward and Beck's servants hurriedly closed the door; Beck was unfortunately left outside with the mob. They beat him, but allowed him to climb over the wall into William Browett's store-room. Five minutes later the crowd followed and got him out; they placed him in a hand-cart, threw him in the mud in Ironmonger Row, and knocked him senseless. When he recovered John Deeming said: "Let us make him swear he knows no one"; Beck was dragged home and made to order his servants to open the door; he was threatened with death if he did not. "Now, you bugger, I will make you destroy your own invention", said one man. The mob surged into the loomshop and Thomas Burbury called out: "Fire it, fire it!"; the windows were smashed, silk was ripped from the looms and thrown out of the windows, and the looms were broken with hammers and iron bars lying to hand. Then the mob set fire to the wreckage. There was a great deal of dry wood in the house and very quickly the fire had caught hold; within twenty minutes the roof fell in; by 4 p.m. the house was in ruins. Meanwhile, Beck had escaped to the privy when the weavers entered the loomshop; a man came to the door and said: "The only way to save your life is to be missing." Beck left but was found in an entry by William Westwick, who said: "You bugger, will you do so any more?"; presumably Westwick meant to ask if he would weave by steam again. Beck said he would not, was given three or four more blows by the weavers, made his escape to Mrs Russell's house in Hill Top, where he did under the dresser, and when followed again by the mob went to Mr Moy's timber yard, where he had a good view of his burning house. ${ }^{2}$ William Wood, Woodhouse's superintendent, hid in the garret behind some silk reels as the mob broke the looms; when the floor was burning beneath his feet, he tied a blanket to a bed post and let himself out of a window to the ground.

The magistrates arrived at the factory during the fire. The Riot Act was read. All the soldiers available were called out from the barracks, 400 yards from Beck's mill; they amounted to fourteen men, from the 14th Light Dragoons and the 7th Hussars, under Lieutenant-Colonel Ewart. Few though they were, the soldiers dispersed the mob without difficulty or violence, cleared the streets, and stood guard at the gaol,

1 Ibid., pp. 220ff., a highly circumstantial account of the day by Edward Goode, David Smith and George Baddeley; Report on the Silk Trade, p. 57.

${ }^{2}$ Coventry Herald, 11 November 1831; 30 March 1832. 
the gasworks and John Day's loomshop to prevent further trouble. Shops, public houses and the theatre were closed. Four hundred special constables were sworn in. ${ }^{1}$ Among them were the seven members of the weavers' committee, eager from the first to assist in suppressing the riot.

"' 'Supposing,' they said to the magistrates, 'they were sworn in as special constables, would it prevent them from attending to their interests as weavers?' The mayor, Thomas Morris, Esq., answered, 'Most assuredly not; it would show that they were good men, and honest men, and afford a stronger proof of their fitness to attend to that duty'."

The special constables and the soldiers patrolled the streets all night, the seven taking their station with a sergeant in front of Day's house "on account of the exclamations which had been made by some of the mob against him". But the night was quiet. ${ }^{2}$ The following morning the Coventry postmaster wrote to Melbourne to tell him that the city was "perfectly tranquil" and had no appearance of being disturbed again. ${ }^{3}$ The suspected ringleaders were arrested and held for trial. Later in the week six companies of the 21st Foot arrived in Coventry, en route from Ireland to Weedon; one company remained in Coventry barracks because of the disturbances but was not needed. ${ }^{4}$ The burning of Beck's mill was followed by no similar acts.

At the Coventry Lent Assizes in March 1832 the accused were tried under a consolidating statute of 1827 , which made it a felony to destroy textiles in the course of manufacture or machinery used for their manufacture. The statute declared riotous and tumultuous assembly leading to the destruction of buildings or machinery a capital felony, ${ }^{5}$ and this was the charge against the accused. Four (three of them weavers) were found not guilty on the main charges and were discharged. The evidence against three others was damning: Thomas Burbury, aged 22, Benjamin Sparkes, aged 20, and Alfred Toogood, aged 17; Toogood's occupation cannot be discovered; Sparkes was a whitesmith, Burbury a weaver and perhaps also a cattle dealer. ${ }^{6}$

1 Serjeant Adams's brief in the case of Merry and Brown versus the inhabitants of the County of the City of Coventry, pp. 4ff., CRO, Box labelled "Anti-machine riots, 1831"; T. Morris to Melbourne, 8 November 1831, HO 52/15; Coventry Herald, 11 November 1831.

2 Report on the Handloom Weavers, Midland District, p. 221.

3 Samuel Vale to Melbourne, 8 November 1831, HO 40/29.

4 Coventry Herald, 11 November 1831.

5 An Act for consolidating and amending the laws in England, relative to malicious injuries to Property [7\&8 George IV, c. 30], sections 3, 8 .

- A Report of the Trial of the Prisoners charged with Rioting and Destroying 
Burbury was the first to burst open the door of the loomshop and his words to the men behind him were held to have instigated the arson. Toogood and Sparkes were seen to break machinery; Sparkes also pulled silk out of the looms, and held Beck while the crowd beat him. The judge, Sir James Parke, admitted that Burbury tried to save Beck from the violence of the crowd. Little harm was in fact done to Beck, who suffered no permanent injury. Nobody else suffered at all. But the law was as much intended to protect property as persons and, as the judge's summing-up shows, was concerned above all with the economically subversive nature of the crime, and the need to deter others with savage sentences, rather than with the value of the property destroyed. ${ }^{1}$ All three were found guilty and were sentenced to death, though the judge told Toogood that in view of his youth he would recommend mercy to the Crown; but he would certainly be transported. The jury had recommended mercy for all three: Parke showed none to Burbury and Sparkes. "In passing sentence of death upon you I feel much reluctance, but I could not let it pass that in a great commercial city like this, such outrages on property could be tolerated; you are therefore to expect no mercy here."2

There was much sympathy for Burbury and Sparkes in Coventry. "A feeling of unfeigned sorrow for the probable fate of the two unfortunate men condemned to die is manifest among all classes in the city and neighbour hood, and the most strenuous exertions are making to procure a remission of the sentence."'3 Many signed a petition for mercy. Preparations were made to execute them on 11 April, and the Coventry sheriffs feared that an attempt might be made to rescue them in the narrow streets that lay on the route from the gaol to Whitley Common. But in the event the sentences were commuted to transportation for life, owing to the intercession of Edward Ellice. In May Burbury, Sparkes and Toogood left the gaol for Portsmouth, to begin their journey to Tasmania. ${ }^{4}$

Before November 1831 none of the rioters are mentioned in the sources; they were not active in the weavers' movement or politics; they did not speak at meetings. None seems to have been in trouble

the Machinery of Josiah Beck (Coventry, 1832); Coventry Herald, 11 November 1831 .

1 A jury eventually decided that the value of the property destroyed was $£ 2,135$. Very little property was stolen during the riot.

${ }^{2}$ Coventry Herald, 30 March 1832.

${ }^{3}$ A Report of the Trial, op. cit., p. 8.

4 John Ralphs and Thomas Pepper to Melbourne, 30 March 1832, HO 52/20; Campbell to S. M. Phillips, 3 April 1832, HO 40/30; Coventry Herald, 30 March to 11 May 1832 . 
previously. At the trial their leader, Burbury, was given a good character. Also, he attended Whitefriars Lane chapel. ${ }^{1}$ Thus in proximate and detailed ways, the Beck mill-burning reminds one of the Swing attacks of 1830 and 1831: these too combined the destruction of property with little looting, or harm to persons, and were committed by youthful and respectable labourers and craftsmen not otherwise known to history. ${ }^{2}$ So the Beck riot was similar to the attack on Pyt House farm, in Wiltshire, just one year before. A mob of 500 marched to Pyt House and destroyed two threshing machines; stones were thrown at the owner when he reproved the rioters, but he was not seriously molested. Tragedy occurred after the yeomanry arrived. They charged the crowd; a battle took place; one man was killed. But until then the rioters behaved with restraint. So did the crowd that destroyed Lane's paper mill in West Wycombe, Buckinghamshire (also in November 1830): a man who threw four gallons of vitriol at the attackers was merely ducked in a pond. ${ }^{3}$ In one essential respect, however, these and other Swing attacks differed considerably from the Beck mill-burning. They were planned and organised; mobs marched to their destinations carrying tools and weapons and with the clear, announced intention of destroying machinery. No doubt Burbury and company were influenced by their knowledge of Captain Swing's assaults, but the detailed record of the Beck incident shows it to have been in the truest sense spontaneous; the crowd stumbled into riot, which was uniquely unplanned and unconsidered. This was how the weavers' leader Benjamin Poole regarded it; he could not really explain how the affair happened. ${ }^{4}$ In other words, the riot took place under the exact conditions where one would expect anger to result in uncontrolled violence: the discipline and moderation of the mob are all the more remarkable, and demonstrate that these qualities were profoundly instinctive and habitual in Coventry. Superficially an

1 George Rudé, “Thomas Burbury", in: Australian Dictionary of Biography, 1788-1850, I (1966), states that Burbury was the son of an army officer who had served on Wellington's staff. Burbury's great-granddaughter, Mrs W. Sinclair of North Balwyn, Victoria, Australia, has discovered while collecting material on the family history that Professor Rudé is mistaken on this point and that Burbury's father was most probably a non-commissioned officer.

${ }^{2}$ E. J. Hobsbawm and George Rudé, Captain Swing (1973), ch. 12. See also the comments on incidents of this sort in George Rudé, "The 'Pre-Industrial' Crowd", in Paris and London in the Eighteenth Century (1970), pp. 17ff.; and Charles Tilly, "Collective Violence in European Perspective", in: The History of Violence in America: Historical and Comparative Perspectives, ed. by H. D. Graham and T. R. Gurr (1969), esp. pp. 16ff.

${ }^{3}$ Hobsbawm and Rudé, Captain Swing, pp. 97-98, 114; J. L. and B. Hammond, The Village Labourer 1760-1832, fourth ed. (1927), pp. 237-38.

* Report on the Silk Trade, p. 57. 
aberration from the long tradition of pacific labour relations in the city, the mill-burning was in fundamental ways its epitome.

When Beck's mill was burnt down the weavers of Coventry had suffered three years of disastrous slump. Earnings had been drastically cut. Many were unemployed. Pauperism was common. In addition, the rioters had without doubt been perpetrators, victims or witnesses of the brutal violence at the parliamentary election of 1826 , and among the crowd of 15,000 that in August 1831 watched the hanging of Mary Ann Higgins, aged nineteen; she had poisoned her uncle for the sake of a few guineas so that she might marry. ${ }^{1}$ Violent and degrading scenes were customary in Coventry. What requires explanation is not the occurrence of industrial violence, but its relative infrequency and moderate nature. Also, though authority encouraged electoral mobs and punished industrial criminals severely, this contrast does not sufficiently explain the differences in popular activity. The inadequacy of the police and the wide dispersion of masters' premises gave much opportunity, especially at night, for anonymous terrorism of the sort suffered by John Day. One overriding cause of the weavers' moderation is the city's paternalism, and the need to reciprocate for it. The city might sympathise with industrial violence - as in the case of the Beck mill-burning -, but it could not approve incidents more frightening than the "visitation" suffered by Farrington's weavers, or the meticulously orchestrated ritual of donkeying, carefully combining ostentatious uproar with no permanent harm to person or property. The weavers' leaders, in constant touch with the city establishment, argued effectively to their followers the need to avoid tumult so as to retain paternalist support; their attitude is most dramatically shown by their enrolment as special constables at the mill-burning, though one of them, Edward Goode, wrote soon after that he agreed with the other weavers in loathing steam power as an aggravation of surplus labour and a threat to the list of prices, and that "the pauperising effects of steam power, as applied to manufactures" might be seen "at Manchester and other places". ${ }^{2}$

Despite the spontaneous and unplanned nature of the mill-burning, it had the effect of the "collective bargaining by riot" that inspired much similar destruction. ${ }^{3}$ The burning frightened the manufacturers into concession, indeed was more fruitful than all the moral suasion preceding it. Beck decided not to make any more ribbons by steam; John Day agreed in future to pay by the piece. Most important, the day after the riot, manufacturers and weavers re-enacted the list

1 Coventry Herald, 12 and 19 August 1831.

2 Ibid., 4 May 1832.

${ }^{3}$ E. J. Hobsbawm, "The Machine Breakers", in Labouring Men (1964), pp. 5ff. 
prices of 1829. All manufacturers agreed to the list, and set up a committee of twenty to watch over it. One master, Cleophas Ratliff, said that the aim of the new list was to give the poorest weaver a bare subsistence if he were fully employed; below that point he ought not to be allowed to drop. The list, said the Coventry Herald, "will induce every manufacturer to resort to some other means of success than that he can find in his own hardness of heart". ${ }^{1}$ The vigilance of weavers and masters, anxious to "prevent the recurrence of the inconveniences and evils that attended the manufacture in 1831 ", ${ }^{2}$ kept the list firm for two years, but then the committee's attention relaxed and the list came under increasing strain. ${ }^{3}$ Weavers, city and paternalist manufacturers had to fight constantly to sustain it from the end of 1833 onwards. ${ }^{4}$

\section{$\mathrm{V}$}

The French ribbons that upper-class women had been buying since the opening of the ports in 1826 helped to create from the mid 1830's onwards a growing market for cheaper ribbons modelled on them. To the new lower-class consumers differences in price were important, and so the cost-advantage Coventry enjoyed by virtue of the tariff on imports enabled the city to exploit the market profitably, often by directly copying French designs. So the ending of prohibition, though damaging in the short term, eventually benefited the city. The list of prices, after many vicissitudes, was not seriously challenged for eighteen years from 1842 onwards. " "The last ten years", wrote the Coventry Herald in 1851, "shows a state of yearly increasing prosperity in Coventry, and its working classes have probably been better off than most other towns in the kingdom."' The demand was met by steam looms and the factory, widely introduced from the 1840's onwards and now freely accepted by the weavers. Twenty years after, the Beck mill-burning was only hazily remembered in the city: in 1852 Harriet Martineau, after visiting Coventry, wrote about Beck's mill that "it was burned down during a quarrel about wages, - nobody knows how or by whom".?

1 Coventry Herald, 11 November 1831.

2 Ibid., 15 November 1833.

3 Report on the Silk Trade, pp. 59ff.; Report from the Select Committee on the Handloom Weavers [PP, 1835, XIII], pp. 232ff.; Report on the Handloom Weavers, Midland District, pp. $221 \mathrm{ff}$.

4 Searby, "Weavers and freemen", pp. $236 \mathrm{ff}$.

Ibid., pp. $211 \mathrm{ff}$.

- Coventry Herald, 1 August 1851.

7 Harriet Martineau, "Rainbow Making", in: Household Words, 14 February 1852. The article was attributed to her by the Coventry Standard, 12 March 1852. 
At the same time, Thomas Burbury was prospering in Tasmania. In 1834 he became a constable, and hunted sheep-stealers and bushrangers energetically. He arrested one notorious band single-handed: "I [did] that which twenty men would have been frightened to have done in England; but liberty or death I was determined to have." So in 1839 Burbury was given a free pardon and a testimonial fund. He quickly added to the land he had for years been buying in his wife's name, and by 1842 was a wealthy farmer. ${ }^{1}$ Elections to Oatlands municipal council followed; until his death in 1870 he took part in "every public movement in the district and was a member of every public body, commanding general esteem and confidence". ${ }^{2}$

1 Coventry Herald, 13 September 1839; 8 April 1842.

2 Rudé, "Thomas Burbury", loc. cit. 